\title{
IMPACT OF ORGANIC AND INORGANIC FERTILIZERS ON SOME SOIL PROPERTIES AND PLANT GROWTH.
}

Husein, M.E. ${ }^{1}$; Mervat S. Hassan ${ }^{2}$; Amal L . Abd EL- Latif ${ }^{1}$; M. H. Abdel-Aal ${ }^{3}$ and

Fatma A - El. Abd El-Salam ${ }^{2}$

${ }^{1}$ Soil Scinces , Debt. Fac. of Agriculture, Cairo University

${ }^{2}$ Department of Forage and Food Research, Cairo, Egypt.

${ }^{3}$ Soils, Water and Environment Research Institute, Agriculture Research Center,Giza, Egypt

\begin{abstract}
A field experiment was carried out at the Experimental Station, Faculty of Agriculture, Cairo University, Giza, Egypt, during 2013\& 2014 summer seasons. The field experiment was laid out in a Randomized Complete Blok Design with three replicates. The experiment involved the following five treatments: (Control) $100 \%$ mineral-N $\left(\mathrm{T}_{1}\right), 100 \%$ organic as compost $(6$ ton fed $\left.{ }^{-1}\right)\left(\mathrm{T}_{2}\right), 75 \%$ organic $\left(4.5\right.$ ton fed $\left.{ }^{-1}\right)$ plus $25 \%$ mineral-N $\left(\mathrm{T}_{3}\right), 50 \%$ organic $\left(3.0\right.$ ton fed $\left.{ }^{-1}\right)$ plus $50 \%$ mineral-N $\left(\mathrm{T}_{4}\right)$ and $25 \%$ organic $\left(1.5\right.$ ton $\left.\mathrm{fed}^{-1}\right)$ plus $75 \%$ mineral-N $\left(\mathrm{T}_{5}\right)$. This investigation was conducted to study the effect of inorganic and organic nitrogen with different combination between them on yield of sorghum and soil properties. The results showed that the bulk density and $\mathrm{pH}$ values in soil was reduced by increasing the organic manure rates, while total porosity was increased by addition of organic fertilizer.. Available N, P and K in soil were increased significantly by different addition rates compared with control. The available nitrogen was significant increased with $\mathrm{T}_{2}$ treatment than other treatments. Available phosphorus and potassium in soil were significantly affected at $\mathrm{T}_{3}$ treatment compared with the others treatments. Available $\mathrm{Fe}, \mathrm{Mn}$ and $\mathrm{Zn}$ were affected by application of compost only and combined with mineral fertilizers, where the available $\mathrm{Fe}$, Mn and $\mathrm{Zn}$ in soil increased with $T_{2}$ treatment compared with the others treatments. The statistical analysis revealed that $T_{3}$ treatment at first cut gave the highest values of both fresh and dry weight compared with other treatments. The results showed that nitrogen, phosphorus and potassium uptake by plants were significantly increased with $\mathrm{T}_{3}$ treatment was the best one at the first cut.

Keywords : Organic nitrogen , inorganic fertilizers , combination, sweet sorghum yield, soil properties
\end{abstract}

\section{INTRODUCTION}

Organic farming practices have been associated with improved soil properties through a number of considerations including the addition of soil organic matter, increased earthworm population, biodiversity, soil fertility etc. , Pulleman et al.,( 2004). Moubarak, et al., (2007) reported that organic amendments significantly produce dry mater yield. Similarly, contents of $\mathrm{N}, \mathrm{P}, \mathrm{K}, \mathrm{Mg}, \mathrm{Ca}, \mathrm{S}$ and trace elements were significantly higher with application of organic fertilizer compared to in organic fertilizers. Muhammad and Khattak,( 2009) reported that organic manures may increase soil fertility and thus the crop production potential possibly by changes in soils physical and chemical properties including nutrient bio-availability, soil structure, water holding capacity, soil $\mathrm{pH}$ and activity of microbial community.

Rehan et al., (2004) revealed that added compost influenced the total soluble salts and their composition in saturated soil paste extract. EC values were higher by using salty compost than those of using slight salt compost.

Also,they found that the soil $\mathrm{pH}$ decreased of both surface and subsurface soil layers increased considerably at the end of the first season (after faba bean) due to compost application.

Hammad et al, (2006) showed that integration of composted rice straw plus nitrogen fertilizer increased the availability of $\mathrm{Fe}, \mathrm{Mn}$ and $\mathrm{Zn}$ in tested soil.

El-Sebaey (2006) found that the addition of composted manure $\left(50 \mathrm{~kg} \mathrm{~N} / \mathrm{fed}^{-1}\right)+$ Inoculation gave higher values of $\mathrm{N}, \mathrm{P}$ and $\mathrm{K}$ uptake than the full does $\left(100 \mathrm{~kg} \mathrm{~N} / \mathrm{fed}^{-1}\right)$ of inorganic $\mathrm{N}$ - fertilizer or organic manure. Bashandy, Samah (2007) observed that NPK uptake of crops grown on date palm waste compost was significantly higher than that of crops grown on the untreated soils. Khaled et al., (2011) reported that organic manure substantially improved shoots and root dry weights. This improved growth was mainly due to increased soil nutrient availability and uptake by plants. Muhammad et al., (2014) found that total dry matter yield of sorghum significantly affected by the application of different organic materials composted. This investigation was conducted to study the effect of inorganic nitrogen (in form of ammonium nitrate 33.5 $\%)$ and organic nitrogen (in form of animal compost) with different combination among them on yield and yield quality of sorghum.

\section{MATERIALS AND METHODS}

A field experiment was carried out at the Experimental Station, Faculty of Agriculture, Cairo University, Giza, Egypt on May $15^{\text {th }}$ in both seasons (2013 and 2014). This investigation was conducted to study the effect of inorganic nitrogen (in form of ammonium nitrate $33.5 \%$ ) and organic nitrogen (in form of animal compost) with different combination among them on yield and yield quality of sorghum. Some chemical properties of used compost are shown in Table 1

Soil samples from the upper $30 \mathrm{~cm}$ layer of soil were taken from farm of research station, where air dried, crushed and prepared to physical and chemical properties determination as shown in Table 2. 
Table 1. Some chemical properties of used compost

\begin{tabular}{lccc}
\hline Characters & Values & Total contents (\%) & Values \\
\hline EC $\left(\mathrm{dSm}^{-1}\right)(1: 10)$ & 4.68 & $\mathrm{~N} \mathrm{\%}$ & 1.70 \\
$\mathrm{pH} \quad(1: 10)$ & 7.22 & $\mathrm{P}$ & 0.002 \\
$\mathrm{O} \mathrm{M} \%$ & 44.15 & $\mathrm{~K}$ & 0.200 \\
$\mathrm{O} \mathrm{C} \%$ & 25.67 & Total contents.(mg/kg) & 29.77 \\
$\mathrm{C} / \mathrm{N}$ ratio & 15.1 & $\mathrm{Fe}$ & 27.83 \\
Moisture content \% & 14.40 & $\mathrm{Mn}$ & 7.80 \\
\hline
\end{tabular}

Table 2. Some physical and chemical properties of the experimental soil before cultivation.

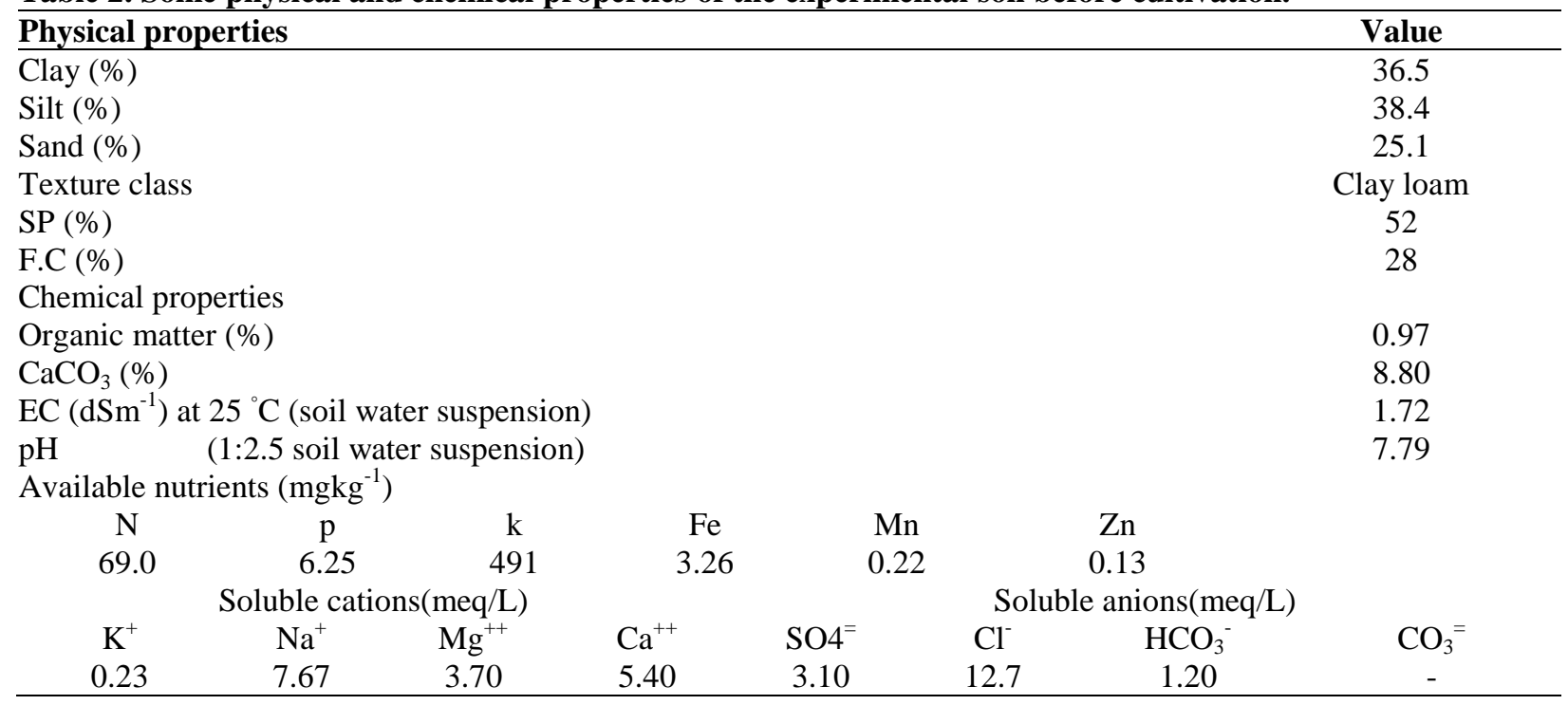

The experiment was done on May15 $5^{\text {th }}$ in both seasons. Each plot $(4 \mathrm{X} 3 \mathrm{~m}$.) was sown with $200 \mathrm{~g}$ grains of sorghum variety Dorado. The surface irrigation was done. The Equal three doses of nitrogen were added according to the planned design. The experiment was conducted in field including the five treatments of different combinations of organic manure and mineral $\mathrm{N}$ :

T1) $100 \%$ mineral $-\mathrm{N}$ ( control ).

T2) $100 \%$ organic ( 6 ton fed $^{-1}$ ) without any mineral fertilizer.

T3) $75 \%$ organic (4.5 ton fed ${ }^{-1}$ ) plus $25 \%$ of recommended-N.

T4) $50 \%$ organic (3.0 ton fed ${ }^{-1}$ ) plus $50 \%$ of recommended-N.

T5) $25 \%$ organic $\left(1.5\right.$ ton fed $\left.{ }^{-1}\right)$ plus $75 \%$ of recommended-N.

Three cuts of sweet corn (sorghum) were fresh weighted; dried at $70 \dot{C}$ in electric oven and weighted the dry plant material of each was ground and prepared for nutrient contents and uptake.

Compost $\mathrm{pH}$ in (1: 10 compost: water suspension), total soluble salts in

(1: 10) carbon method, were determined according to Page et al. (1982). Total nitrogen in compost samples, were determined using Keldahl digestion method as described by Jackson (1973).Total phosphorus, potassium, iron, zinc, and manganese were determined in the extract described by Brunner and Wasmer (1978). Phosphorus was measured spectrophotometrically, potassium by flame photometer and micronutrients by atomic absorption instrument.

Partical size distribution was carried out by pipette as described by Gee and Bauder (1986).Bulk density and total porosity was determined according to (Jackson, 1973). Saturation percent (S.P) was determined according to Hesse (1971). Calcium carbonate was estimated volumetrically using the Collin's Calcimeter (Sparks, 1996). Electrical conductivity (E.C.) was measured in soil paste using the method described by Page et al., (1982). Soluble cations: $\mathrm{Ca}^{+}$and $\mathrm{Mg}^{+}$were measured by versinate method, while $\mathrm{Na}^{+}$and $\mathrm{K}^{+}$were measured using Flame photometer, according to Page et al., (1982). soluble anions: $\mathrm{CO}_{3}^{-}, \mathrm{HCO}_{3}^{-}$and $\mathrm{Cl}^{-}$were determined titrimetrically according to Page et al., (1982).pH value was determined in (1: 2.5 soil-water suspension) using a glass-electrode pH-meter (Page et al., 1982) . Organic matter content was determined according to the Walkley and Black titration method (Sparks, 1996). Available nitrogen in the soil samples was extracted with $2.0 \mathrm{~N}$ KCL, according to Hesse, (1971) and determined by using micro-kjeldahl apparatus. Available phosphorus and Available potassium were determined by using according to Sparks, (1996)

Available micronutrients (Fe, $\mathrm{Mn}, \mathrm{Zn})$ were extracted by "NH $\mathrm{HCO}_{3}-\mathrm{DTPA}$ according to Soltanpour (1985) and determined by using Atomic Absorption Spectrophotometer Perkin Elmer, Model 2308. 
The wet digestion method was used according to determine nitrogen Phosphorus and potassium in plant as described by Page. et al.,(1982). The obtained data were statistically analyzed according to the methods described by Snedecor and Cochran (1980) using computer M. Stat. program.

\section{RESULTS AND DISCUSSION}

\section{Soils properties as affected by organic and mineral fertilizers:}

a) Physical properties:

Bulk density and total porosity of soil:

The analysis reveal that the bulk density(BD) values were reduced by increasing the compost rates, where the compost alone effected on bulk density over than combined with mineral .Results in Table 3 could be enhanced with Sarkar et al. ( 2003), who reported that application of organic fertilizers alone decreased the bulk density.

\section{Total porosity in soil}

Data show that total porosity (TP) values were increased by increasing organic manure addition rates, where the $T_{2}$ and $T_{3}$ gave highest values of total porosity compared with other rates (Table 3 ). Generally, the reduced of bulk density values led to increase of total porosity in soil. Such increase is an indication of soil aggregation in forms leading to improved soil structure and increased porosity. This result could supported with those obtained by Habtamu (2015) who showed that integrated application of organic and inorganic fertilizers improved soil total porosity and decreased bulk density by $26.1 \%$ in $0-30 \mathrm{~cm}$ soil depth.

\section{b) Chemical properties:}

Soil salinity (EC), pH and organic matter:

Data of soil salinity (EC) after sorghum cultivation expressed are presented in Table 3. The results show that the higher rate of manure application treatment was of the highest EC values significantly, while by increasing mineral raised significantly EC values only in $T_{1}$ more than other treatments. this result is in agreement with Badawi, (2003) who reported that electrical conductivity values (EC) increased by application of different types and rates of composted plant residues.

These results reveal that the treatment of compost alone affected soil $\mathrm{pH}$ more than combined with mineral fertilization, where soil $\mathrm{pH}$ values reduced with high addition rates of organic manure compared with mineral fertilizers only or combined. Gehan, (2006) found that application of compost and different mineral nitrogen fertilizer rates, decreased slightly the $\mathrm{pH}$ values in tested soil.

The results indicate that the organic matter content increased significantly by increasing compost, the most effective treatment which decreased bulk density (BD) was addition of organic materials which must have enhanced soil aggregation which increase the apparent soil volume and consequently decrease bulk density. Modaihsh et al, (2005) found that application of composts at the highest rates increased the organic matter content in tested soil.

Table 3. Some physical and chemical properties of the experimental soil at the end of the experiment.

\begin{tabular}{lccccc}
\hline \multirow{2}{*}{ Treatments } & EC dS/m & Chemical properties & \multicolumn{2}{c}{ Physical properties } \\
& 1.45 & $\mathbf{p H}$ & O.M \% & BD & TP \\
\hline T1 & 1.71 & 7.18 & 1.13 & 1.58 & 1.24 \\
T2 & 1.48 & 7.87 & 1.80 & 1.35 & 18.20 \\
T3 & 1.44 & 8.02 & 1.53 & 1.39 & 15.76 \\
T4 & 1.38 & 7.85 & 1.39 & 1.43 & 13.33 \\
T5 & 1.49 & 7.93 & 1.33 & 1.50 & 9.09 \\
mean & 0.0834 & 0.098 & 0.110 & 1.45 & 12.12 \\
L.S.D. at 0.05 & & & & 0.018 & 0.248 \\
\hline
\end{tabular}

\section{Available NPK in soil}

Results reveal that available nitrogen amounts in soil were increased significantly by different addition rates compared with control, where the T2 treatment was significantly highest value Table 4 . While results indicat that available $\mathrm{P}$ and $\mathrm{K}$ were significantly affected at $\mathrm{T}_{3}$ treatment than the other treatments. Generally, available NPK increased by compost application which have direct effect of compost and nutrients associated with .Khaled et al., (2011) found that the $\mathrm{N}, \mathrm{P}$ and $\mathrm{K}$ concentrations in stover of zea maize pronounced increased with increasing rates of compost and organic farm in soil.

\section{Available Fe-Mn-Zn in soil}

Data reveal that application of compost only or combined with mineral fertilizers were increased available Fe, Mn and $\mathrm{Zn}$ amount compared with control Table 4. Also, available $\mathrm{Fe}, \mathrm{Mn}$ and $\mathrm{Zn}$ values were increased by increasing the application rate organic manure. These results could be enhanced with those obtained by Mostafa, et al. (2001) who found that the application of organic manures consistently increased availably $\mathrm{Fe}, \mathrm{Mn}$ and $\mathrm{Zn}$ contents in soil.

Modaihsh .,et al (2005) showed that application of composts at the various rates increased the available $\mathrm{Zn}$ in the tested soil. Hammad et al., (2006) showed that integration of composted rice straw plus nitrogen fertilizer increased the availability $\mathrm{Fe}, \mathrm{Mn}$ and $\mathrm{Zn}$ in tested soil. 
Table 4. Available concentration of some nutrients in soil after cultivation $\left(\mathrm{mg} \mathrm{kg}^{-1}\right)$.

\begin{tabular}{lcccccc}
\hline Treatments & $\mathbf{N}$ & $\mathbf{P}$ & $\mathbf{A v a i l a b l e ~ c o n c e n t r a t i o n ~} \mathbf{( m g ~ \mathbf { ~ k g } ^ { - 1 } )}$ & $\mathbf{\text { Ke }}$ & $\mathbf{M n}$ & $\mathbf{Z n}$ \\
\hline T1 & 70.50 & 5.37 & 523.33 & 3.63 & 0.89 & 0.47 \\
T2 & 109.83 & 9.46 & 542.00 & 3.83 & 1.00 & 0.52 \\
T3 & 85.00 & 10.88 & 587.00 & 4.37 & 1.15 & 0.51 \\
T4 & 77.50 & 8.92 & 551.17 & 3.40 & 0.96 & 0.46 \\
T5 & 64.17 & 7.50 & 572.50 & 3.25 & 0.78 & 0.39 \\
Mean & 81.4 & 8.40 & 555.2 & 3.69 & 0.96 & 0.47 \\
L.S.D.at 0.05 & 2.010 & 1.380 & 12.510 & 0.359 & 0.111 & 0.096 \\
\hline
\end{tabular}

\section{Fresh and dry weight}

Data in Table 5 show that fresh and dry weight values of sorghum plants were affected by different application rates of organic and inorganic fertilizers.

It was noticed that the fresh and dry weight values affected by different rates, where $\left(T_{3}\right)$ gave the highest values of both fresh and dry weight compared with other treatments. Generally the fresh and dry weight values were increased at $\left(\mathrm{T}_{3}\right)$ compared with the control.

Regarding to the cuts of sorghum plants, data appear that fresh and dry weight values of sorghum plants was increased with 1 st Cut compared with the other cuts, where the order was $1^{\text {st }} \mathrm{Cut}>2^{2^{\text {nd }}} \mathrm{Cut}>3^{\text {rd }} \mathrm{Cut}$.
Concerning the interaction between application rates and cuts, statistically analysis revealed that there was significant effect among them of both fresh and dry weight. Where $\left(\mathrm{T}_{3}\right)$ at $1^{\text {st }}$ Cut gave the highest values of both fresh and dry weight compared with other treatments. These results almost agree with that obtained by Abo-El-Soud et al (2006) and Gehan (2006) reported that the use of compost at the rate of $20 \mathrm{~m}^{3} / \mathrm{fed}$ $(\mathrm{OM})$ in combination with the high rate of nitrogen fertilizer had significantly affected the dry matter content. Muhmmad et al., (2014) found that total dry matter yield of sorghum significantly $(\mathrm{p} \leq 0.05)$ affected by the application of different organic materials.

Table 5. Fresh and dry weights of sorghum as affected by organic and mineral fertilization (ton. $/$ fed $\left.^{-1}\right)$.

\begin{tabular}{|c|c|c|c|c|c|c|c|c|}
\hline \multirow{2}{*}{ Treatments } & \multicolumn{3}{|c|}{ Fresh weight $\left(\right.$ tonfed $\left.^{-1}\right)$} & \multirow{2}{*}{ Mean } & \multicolumn{3}{|c|}{ Dry weight $\left(\right.$ tonfed $\left.^{-1}\right)$} & \multirow{2}{*}{ Mean } \\
\hline & $1 \stackrel{\text { st }}{C} \mathbf{C u t}$ & $2^{- \text {nd }}$ Cut & $3^{\text {rd }}$ Cut & & $1{ }^{\text {st }}$ Cut & $2^{- \text {nd }}$ Cut & $3^{\text {rdd }}$ Cut & \\
\hline$\overline{\mathrm{T} 1}$ & 27.30 & 24.92 & 19.92 & 24.05 & 5.95 & 5.20 & 4.73 & 5.29 \\
\hline $\mathrm{T} 2$ & 28.63 & 28.95 & 17.68 & 25.08 & 6.85 & 5.38 & 4.09 & 5.44 \\
\hline $\mathrm{T} 3$ & 30.77 & 25.69 & 22.96 & 26.47 & 7.52 & 5.19 & 4.90 & 5.87 \\
\hline $\mathrm{T} 4$ & 28.91 & 28.84 & 19.71 & 25.82 & 5.91 & 5.58 & 4.45 & 5.31 \\
\hline $\mathrm{T} 5$ & 28.25 & 26.39 & 21.98 & 25.54 & 6.69 & 5.49 & 4.07 & 5.42 \\
\hline Mean & 28.77 & 26.96 & 20.45 & & 6.95 & 5.30 & 4.45 & \\
\hline \multirow{3}{*}{$\begin{array}{l}\text { L.S.D. at } 0.05 \\
\text { levels }\end{array}$} & \multirow{2}{*}{\multicolumn{2}{|c|}{$\begin{array}{l}\text { Treatments } \\
\text { Cuts }\end{array}$}} & $(\mathrm{T})=0.479$ & & \multicolumn{2}{|c|}{ Treatments } & \multicolumn{2}{|c|}{$(T)=0.354$} \\
\hline & & & $(\mathrm{C})=0.371$ & & \multirow{2}{*}{\multicolumn{2}{|c|}{$\begin{array}{l}\text { Cuts } \\
\text { Interaction }\end{array}$}} & \multirow{2}{*}{\multicolumn{2}{|c|}{$\begin{array}{c}(\mathrm{C})=0.274 \\
(\mathrm{~T} \times \mathrm{C})=0.615\end{array}$}} \\
\hline & \multicolumn{2}{|c|}{$\begin{array}{l}\text { Cuts } \\
\text { Interaction }\end{array}$} & $(\mathrm{T} \times \mathrm{C})=0.831$ & & & & & \\
\hline
\end{tabular}

Nitrogen, phosphorus and potassium uptake by plants

Data in Table 6 show the means of nitrogen and phosphorus uptake in sorghum plants affected by different application rates of compost and mineral fertilizers.

With respect to the application rates, the results show that nitrogen and phosphorus uptake values in plant increased by different addition rates of organic only or combined with mineral fertilizers, $\left(\mathrm{T}_{3}\right)$ treatment produced significantly higher value in both nitrogen and phosphorus uptake compared with the others, the order of nitrogen was $T_{3}>T_{2}>T_{4}>T_{5}>T_{1}$, while phosphorus concentration the order was $\mathrm{T}_{3}>\mathrm{T}_{4}, \mathrm{~T}_{2}$ and $\mathrm{T}_{5}>\mathrm{T}_{1}$ where the $T_{3}, T_{2}$ and $T_{5}$ statistically as the same.

Regarding the cuts of sorghum plants, it was found that nitrogen and phosphorus uptake values significantly increased at first cut compared with others, the order was first cut $>$ second cut $>$ third cut in both of nitrogen and phosphorus uptake.

Concerning the interaction between rates and cuts, the results show that nitrogen and phosphorus uptake by plants were significantly increased with $\left(\mathrm{T}_{3}\right)$ treatment at first cut better than other treatments.

Also, data reveal that potassium uptake by plants was significantly affected by using organic only or combined with mineral fertilizers, where the potassium uptake ranges from 124.5 to $209.2 \mathrm{mg} / \mathrm{kg}$ plant,

With respect to the application rates, the results show that potassium uptake by plants increased by different addition rates of organic only or combined with mineral fertilizers, $\left(\mathrm{T}_{4}\right)$ treatment was gave significantly high value compared with others, where the order was $_{3}>\mathrm{T}_{2}>\mathrm{T}_{4}>\mathrm{T}_{5}>$ control.

It was found that potassium uptake by was plants affected by different cuts of, sorghum plants where the first cut gave high value compared with the other cuts, the order was first cut $>$ second cut $>$ third cut .

Regarding the interaction between application rates and cuts, the results reveal that the best values of potassium uptake by plants were obtained by using $\mathrm{T}_{4}$ at first cut. These results almost could be supported by those obtained by El-Sebaey (2006) found that the addition of compost manure $\left(50 \mathrm{~kg} \mathrm{~N} \mathrm{fed}{ }^{-1}\right)+$ 
Inoculation gave higher values of $\mathrm{N}, \mathrm{P}$ and $\mathrm{K}$ uptake than the full does $\left(100 \mathrm{~kg} \mathrm{~N} \mathrm{fed}{ }^{-1}\right.$.) of inorganic $\mathrm{N}$ fertilizer or organic manure. Also, Hanan. et al., (2013) found that organic fertilizers, (water hyacinth compost) gave the highest mean values of total NPK uptake of sorghum plants

Table 6. Nitrogen, phosphorus and potassium uptake $\left(\mathrm{mg} / \mathrm{kg}^{-1}\right)$ by sorghum plants as affected by organic and mineral fertilization.

\begin{tabular}{|c|c|c|c|c|c|c|c|c|c|c|c|c|}
\hline \multirow{3}{*}{ Treat. } & \multirow{2}{*}{\multicolumn{3}{|c|}{$\begin{array}{l}\text { Nitrogen uptake } \\
\left(\mathrm{mg} / \mathrm{kg}^{-1}\right)\end{array}$}} & \multirow{3}{*}{ Mean } & \multirow{2}{*}{\multicolumn{3}{|c|}{ Phosphorus uptake (mg/kg- }} & \multicolumn{5}{|c|}{ Potassium uptake } \\
\hline & & & & & & & & Mean & & $\left(\mathrm{mg} / \mathrm{kg}^{-}\right.$ & & Mean \\
\hline & 1 $^{\text {st }}$ Cut & $2^{\text {nd }}$ Cut & $3^{\text {rd }}$ Cut & & $1^{\text {st }}$ Cut & $2^{\text {nd }}$ Cut & $3^{\text {rd }}$ Cut & & $\mathbf{1}^{\text {st }}$ Cut & $2^{\text {nd }} \mathrm{Cut}$ & $3^{\text {rd }}$ Cut & \\
\hline$\overline{\mathrm{T} 1}$ & 79.41 & 68.25 & 63.18 & 70.28 & $20.2 \mathrm{e}$ & 20.25 & 17.67 & 19.39 & 150.8 & 124.5 & 129.7 & 135.0 \\
\hline $\mathrm{T} 2$ & 92.28 & 74.25 & 57.4 & 75.65 & 25.88 & 25.09 & 15.98 & 22.32 & 181.7 & 171.4 & 124.6 & 159.2 \\
\hline $\mathrm{T} 3$ & 115.0 & 63.75 & 63.23 & 80.67 & 21.36 & 33.77 & 17.83 & 24.32 & 203.2 & 143.3 & 157.0 & 167.8 \\
\hline $\mathrm{T} 4$ & 93.68 & 70.56 & 55.68 & 73.31 & 29.06 & 21.60 & 19.05 & 23.23 & 209.2 & 154.8 & 89.55 & 151.2 \\
\hline T5 & 85.39 & 76.68 & 51.86 & 71.31 & 31.31 & 19.89 & 15.29 & 22.16 & 177.8 & 148.3 & 117.5 & 147.9 \\
\hline Mean & 93.76 & 70.70 & 58.27 & & 25.57 & 24.12 & 17.16 & & 184.5 & 148.5 & 123.7 & \\
\hline \multirow{3}{*}{$\begin{array}{l}\text { L.S.D. at } 0.05 \\
\text { levels }\end{array}$} & \multicolumn{2}{|c|}{ Treatments } & \multicolumn{2}{|c|}{$(T)=2.862$} & \multicolumn{2}{|c|}{ Treatments } & \multicolumn{2}{|c|}{$(\mathrm{T})=1.374$} & \multicolumn{2}{|c|}{ Treatments } & \multicolumn{2}{|c|}{$(\mathrm{T})=1.411$} \\
\hline & \multirow{2}{*}{\multicolumn{2}{|c|}{$\begin{array}{l}\text { Cuts } \\
\text { Interaction }\end{array}$}} & \multirow{2}{*}{\multicolumn{2}{|c|}{$(\mathrm{C})=2.862$}} & \multirow{2}{*}{\multicolumn{2}{|c|}{$\begin{array}{l}\text { Cuts } \\
\text { Interaction }\end{array}$}} & \multirow{2}{*}{\multicolumn{2}{|c|}{$\begin{array}{c}(\mathrm{C})=0.3735 \\
(\mathrm{~T} \times \mathrm{C})=2.381\end{array}$}} & \multirow{2}{*}{\multicolumn{2}{|c|}{$\begin{array}{l}\text { Cuts } \\
\text { Interaction }\end{array}$}} & \multirow{2}{*}{\multicolumn{2}{|c|}{$\begin{array}{c}(\mathrm{C})=1.093 \\
(\mathrm{~T} \times \mathrm{C})=2.445\end{array}$}} \\
\hline & & & & 954 & & & & & & & & \\
\hline
\end{tabular}

\section{REFERENCES}

Abou El-Soud A.A.; Badawi F. S; Ahlam A. Mehesen and Hasouna B. A.(2006)Effect of bio and organic amendments on growth and yield of maize in newly reclaimed soil. J. Agric. Sci. Mansoura Univ. 31 (6) 3881- 3892

Badawi, F. S. (2003). Studies on bio-Organic fertilization of wheat under newly reclaimed Soils Ph. D. Thesis Fac.Agric., Cairo Univ., Egypt. Pp. 917-934

Bashandy.; Samah S.O. (2007). Recycling of date palm wastes as a Source of Organic Fertilizer. M. Sc Thesis, Fac. Agric. Minia Univ. Egypt.

Brunner, P. H.; and Wasmer, H. R. (1978). Methods of Analysis of Swage Sludge Solids Wastes and Compost. WHO international Reference Center for wastes Disposal. CH-8600 Dubendorf, Switzerland.

El-Sadfy, O. F.; Bioumy, A.M.; and Badawy, A.A. (2005). Response of maize to bio, organic and nitrogen fertilization in sandy soil. Egypt J. Agric. Sci. 20 (11) 269-284.

El-Sebaey M. M. (2006). Effect of inorganic, organic and bio-fertilizer on wheat plant grown in New cultivated land. Zagazig J.Agric. Res., 33 (5) : 863-867.

Gee ,G .W. and Bauder, J .W.(1986).Particle -size analysis,:m:Klute, A.(Ed.), Methods of Soil Analysis, part1: physical and Minera logical Methods .S Sci.Soc.Amer., Madison,WI , PP .383-411.

Habtamu, A. D. (2015). Effects of organic and inorganic fertilizers on selected soil properties after harvesting maize at antra catchment, Northwestern Ethiopia. International Invention Journal of Agricultural and Soil Science (ISSN: 2408-7254) 3 (5): pp. 68-78.

Hammad, S.A.; El-Hamdi, Kh. H.; Ghanem, S.A.; and Naeem, E.S. ( 2006 ). Impact of rice straw on availability of some nutrient elements in flooded rice soils. J. Agric. Sci. Mansoura Univ. 31 (6) : 4007-4015.
Hanan S. Siam.; El Ashry ,S.M.; and Abdel-Moez, M.R. (2013) . Productivity and nutrients uptake of lettuce and sorghum grown on sandy soil as affected by some organic wastes with mineral fertilizers. Journal of Applied Sciences Research, 9(7): 4151-4159.

Hesse, R.R. (1971). A Text Book of Soil Chemical Analysis.Jon Murry (Publishers) Lth, 50 Albermarle Street, London.

Jackson, M. L. (1973). Soil Chemical Analysis.Prentice Hall of India Pvt. Ltd., New Delhi. India. pp. 10- 144.

Khaled, A.; Shaban; Mona, G.; Abd El-Kader, Seham, M.; and El-Khadrawy (2011). Evaluation of organic farm and compost combined with urea fertilizers on fertility and maize productivity in newly reclaimed .Res. J. of Agri. and Bio. Sci., 7(5): 388-397, ISSN 1816-1561.

Modaihsh , A. S.; Taha , A. A.; and Mahjoub, M.O. (2005). Impact of some compost on wheat plant grown in calcareous soils. J. Agric. Sci. Mansoura Univ. 30 (12) 8313-8321.

Mostafa , M. A. ; Gawish S. M ; and. Basyouny E. A (2001) Effect of enriched organic manures with $\mathrm{Fe}$ and $\mathrm{Zn}$ on the availability of $\mathrm{Fe}$ and $\mathrm{Zn}$ in newly reclaimed soils. Minufiya J. Agric. Res. 26 (6): 1667-1680

Mubarak, A. R.; Nazar ,O. S.; Ali, A. H.; and Ahmed, G. M. (2007) Effect of application of organic amendments on quality of forage sorghum (Sorghum bicolor L.) in the semi-arid tropics. Archives of Agronomy and Soil Science; 53(5): 529-538.

Muhammad, S.; Muhammad, A.; Tanvir ,B.; Farmanullah ,K.;Bismillah, J.; and Inamullah Khan.(2014). Growth and phosphorus uptake of sorghum plants in saltaffected soil as affected by organic materials composted with Rock Phosphate. Pak. J. Bot., 46(1): 173-180.

Muhammad, D.; and Khattak, R.A. (2009). Growth and nutrient concentration of maize in pressmud treated salinesodic soils. Soil Environ., 28: 145155 . 
Page A.L.; Miller, R.H.; and Keeney, D.R. (1982). Methods of Soil Analysis 11- Chemical and Microbiological properties. Soil Sci. Amer. Madison Wisconsin, U.S.A.

Pulleman, M.M.; Six, J.; Breemen, N.; and Jongmans, AG. (2004). Soil organic matter distribution and microaggregatecharacteristics as affected by agricultural management and earthworm activity. European Journal of Soil Science, 9: 759-772.

Rehan, M. G.; El-Sayed, A.H.; Hassan, M.M.;and Negm, M.A., (2004). Direct and residual effect of mixing the added compost to calcareous soil with sulphur and phosphorus on crop yields and some soil properties.J.Agric. Sci. Mansoura Univ., 29 (3): 1603 - 1614.

Sparks,D.L.(1996). Methods of Soil Analysis. Part 3, Chemical Methods. Soil Science Society of America book Society of Series, no .5, Madison.
Sarkar, S.; Singh S.R.; and Singh, R.P. (2003). The effect of organic and inorganic fertilizers on soil physical condition and the productivity of a ricelentil cropping sequence in India. J. Agric. Sci. 140, 419-425.

Snedecor, G.W.; and Cochran, W.G. (1980). Statistical Methods,7th_ ed.I owa Stal,univ, press Amer. Iowa, U.S.A.

Soltanpour, P.N. (1985). Use of AB-DTPA soil test to evaluate elemental .

Youssef, Gehan . H. (2006). Effect of rice straw compost and mineral nitrogen fertilizer on some sandy soils chemical properties and nitrogen use efficiency for maize and wheat plants. J. Agric. Sci Mansoura Univ., 31 (9): 6079-61

\section{"تاثير الاسمدة العضوية والغير عضوية على بعض خواص التربة ونمو النبات "

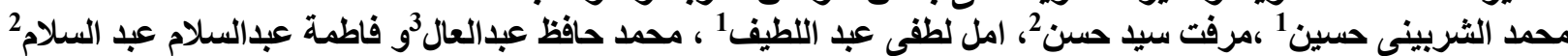

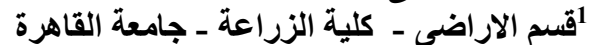

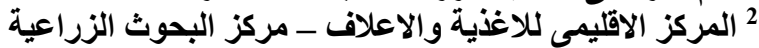

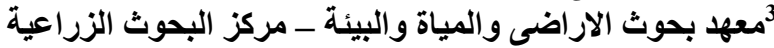

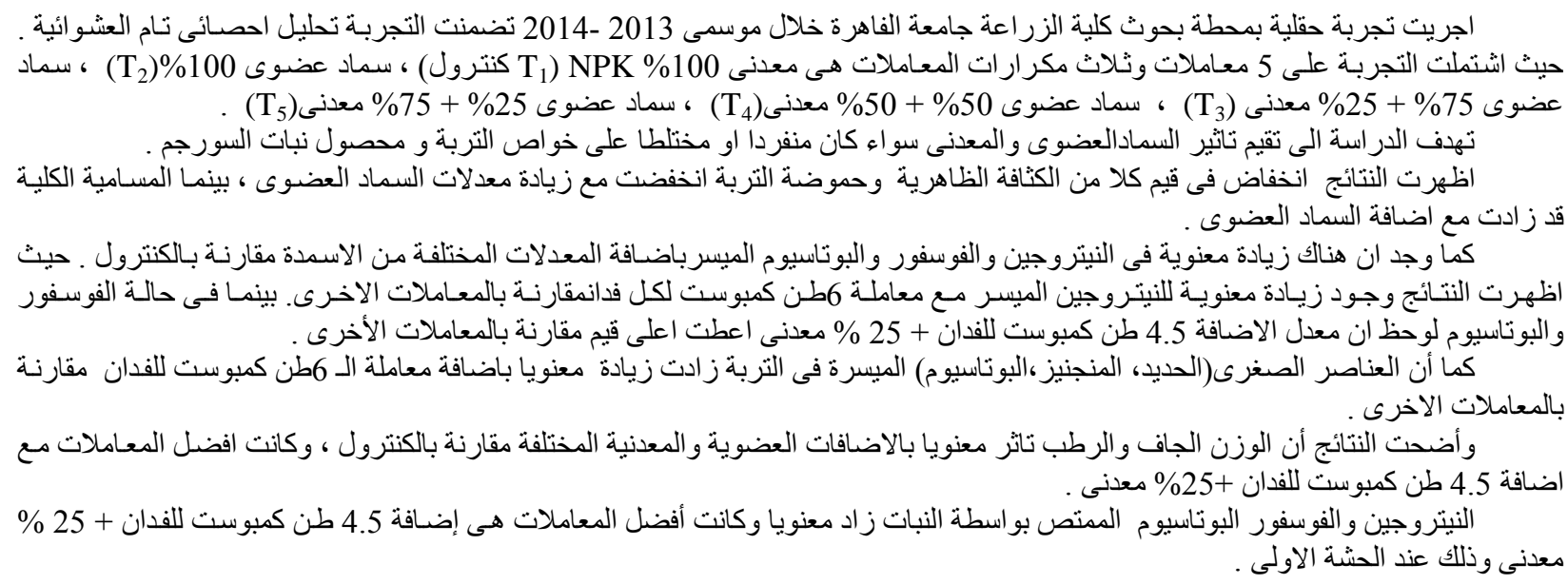

